\title{
Who Gets Targeted for Vote-Buying? Evidence from an Augmented List Experiment in Turkey
}

\author{
Ali Çarkoğlu \\ Professor, Koç University \\ acarkoglu@ku.edu.tr \\ S. Erdem Aytaç \\ Assistant Professor, Koç University \\ saytac@ku.edu.tr
}

\section{This is a pre-copy edited version. Cite as:}

Çarkoğlu, Ali, and S. Erdem Aytaç. 2015. "Who Gets Targeted for Vote-Buying? Evidence from an Augmented List Experiment in Turkey." European Political Science Review 7(4): 547-566.

\begin{abstract}
Understanding the dynamics of vote-buying is essential to improve accountability of elections in developing democracies. While list experiments are useful for attenuating social desirability bias associated with measuring vote-buying, they are not conducive to multivariate analyses, and the question of what types of individuals are targeted is left inadequately explored. We overcome this limitation by combining a population-based list experiment with an estimator (LISTIT) that allows for multivariate analyses in an efficient manner. Our analysis suggests that in the 2011 parliamentary elections of Turkey over one-third of the electorate was targeted for vote-buying, which is more than double the proportion willing to admit when asked directly. Additionally, we find that strong partisans of the ruling Justice and Development Party (AKP), less-educated individuals, and urban residents are significantly more likely to be targeted for vote-buying. We present compelling evidence for the hypotheses that parties target their core supporters and socio-economically vulnerable individuals. The strength of our evidence derives from the use of original data on vote-buying that has been collected in an unobtrusive manner and analyzed at the level of individuals.
\end{abstract}

WORD COUNT: 8667 
The prevalence of vote-buying is one of the most significant weaknesses of democratic processes in developing countries (Schaffer 2007). When individuals exchange their votes in return for cash or minor rewards, the equality of the ballot is undermined, a level and competitive political playing field ceases to exist, and elections are deprived of their policy content (Desposato 2007, Stokes 2007a). This practice directly undermines the role of elections as a vehicle for representation and a mechanism of accountability (Stokes 2007b).

Given the importance of the subject there has been considerable interest in studying votebuying and clientelism in general. However, as one author puts it, "we actually know very little about how widespread the practice is or the correlates of variation" (Weitz-Shapiro 2012, 568). The main culprit is the often hidden and morally indefensible nature of vote-buying that renders reliable data collection difficult in two ways. The social desirability bias associated with measuring vote-buying results in underreporting of its prevalence, and leads to invalid inferences regarding the types of individuals that are being targeted. ${ }^{1}$ Although there have been advances in the literature to obtain accurate estimates of the aggregate levels of vote-buying, a reliable diagnosis of the target individuals is yet to be achieved.

In this article we employ an approach that not only enables us to estimate the prevalence of vote-buying while minimizing concerns of social desirability bias, but is also conducive to the analysis of individual-level determinants of being targeted. Specifically, we combine two methodological innovations in the literature to study the practice of vote-buying in a major developing democracy. While the list experiment technique is useful for addressing the social desirability bias associated with measuring vote-buying, its limitations preclude efficient analysis of multivariate relationships between respondent characteristics and responses (Corstange 2009;

\footnotetext{
${ }^{1}$ This is because the probability of misrepresentation of true behavior might not be orthogonal to important covariates such as income, education, or partisanship (Gallego and Wantchekon 2012).
} 
Blair and Imai 2012). A list experiment in its original form relies on difference-in-means tests that are conducive to estimating the aggregate level of the sensitive behavior only, and it does not allow for individual-level analyses (Kuklinski et al. 1997). Researchers can try to conduct pseudo-multivariate analyses by dividing their sample along variables of interest and running difference-in-means tests or regressions with interaction terms across the resulting sub-groups (e.g., Holbrook and Krosnick 2010; Gonzalez-Ocantos et al. 2012), but these approaches quickly encounter degrees of freedom constraints, are problematic for continuous variables, and do not use the data efficiently (Corstange 2009). Thus, they result in hypothesis tests with low statistical power, and the important question of what types of individuals are targeted for votebuying is left inadequately explored.

We overcome this limitation of list experiments by utilizing a procedure and estimator that allow individual-level multivariate analyses on list experiment data. In particular, we apply a modified version of the list experiment technique and a new estimator (LISTIT) as proposed by Corstange (2009) to original survey data from the 2011 parliamentary elections in Turkey. The results of our analyses illustrate the value of the approach we employ. When asked directly, only $16 \%$ of our sample admitted being targeted for vote-buying. Our experimental evidence, on the other hand, provides an estimate of $35 \%$, more than double of what people report directly. This implies that in the Turkish case approximately one-third of the voting age population was targeted for vote-buying, and almost half of the actual targets were reluctant to reveal this when asked directly. Furthermore, we find that strong partisans of the ruling Justice and Development Party (Adalet ve Kalkınma Partisi, AKP), less-educated individuals, and urban residents are significantly more likely to have been offered material benefits in exchange for vote. 
Our study contributes to the literature in three ways. First, by combining different methodological innovations we are able to explore a number of hypotheses on what types of individuals are more likely to be targeted for vote-buying that previous researches have not been able to address adequately due to limitations of their approaches. The strength of our evidence in comparison to existing studies derives from the use of original data on vote-buying that have been collected in an unobtrusive manner (through a list experiment) and analyzed at the level of individuals (using the LISTIT estimator). We are the first in the literature to present such evidence, and thus are in a position to push the debate on vote-buying forward by providing a reliable diagnosis of the target individuals. ${ }^{2}$

Second, our results lend strong support to theories of vote-buying that predict that parties target their core supporters and socio-economically vulnerable individuals. In the Turkish case vote-buying efforts of the incumbent AKP seem to be focused on individuals who identify themselves very closely with the party, and not on its weak partisans or on individuals who do not identify themselves with any party. Moreover, we find that a particular aspect of socioeconomic vulnerability, namely a low level of education, is correlated with being targeted. Finally, as our study constitutes the first systematic treatment of vote-buying in Turkey, we expand our knowledge on the vote markets, and provide a new insight on the electoral dynamics of an important, large, unconsolidated democracy.

\footnotetext{
${ }^{2}$ We should emphasize that we do not claim to be the first to use the list experiment method to study vote-buying. Gonzalez-Ocantos et al. (2012) and Corstange (2012) have done this as well in Nicaragua and Lebanon, respectively. These studies, however, present analyses at the level of sub-groups only. In contrast, we are able to analyze our data at the level of individuals, which significantly increases the statistical power of hypothesis tests.
} 


\section{Challenges in Diagnosing Vote-buying}

Vote-buying defined as "the proffering to voters of cash or (more commonly) minor consumption goods by political parties, in office or in opposition, in exchange for the recipient's vote" (Brusco et al. 2004, 67) continues to be a widespread phenomenon across the developing world. Figure 1 compiles a number of recent surveys in 27 countries from Latin America, Africa, and the Middle East that asked respondents whether they were offered a material benefit in return for their votes in recent elections. The proportion of individuals responding affirmatively to this question ranges from 6\% (Nicaragua, Uruguay, Chile, Botswana, and South Africa) to $41 \%$ in Uganda. The median country in this sample is Colombia where $15 \%$ of respondents admitted being offered a material benefit in return for their vote.

\section{[FIGURE 1 ABOUT HERE]}

Social scientists frequently rely on self-reported individual opinion and behavior in empirical research, just as the aforementioned figures on the prevalence of vote-buying are based on individuals' self-reported declarations. When studying stigmatized attitudes or illegal behaviors, however, eliciting truthful answers poses a distinct challenge. Survey items that directly ask about sensitive subjects such as racial attitudes, sexual behavior, or vote-buying might lead some individuals to misrepresent themselves, conceal their actions, or simply refuse to respond. Specifically, individuals might choose to show favorable images of themselves to interviewers by giving answers that conform to social norms - a phenomenon known as social desirability bias (Bradburn et al. 1978). Measurement errors that result from social desirability bias and non-response cannot be treated as random, and hence would lead researchers to invalid 
conclusions (Corstange 2009; Blair and Imai 2012). For example, if individuals are disinclined to admit to receiving money or gifts in exchange for votes, then the overall incidence of votebuying would be underreported. Accordingly, the data in Figure 1 most likely represent a lower bound for the prevalence of vote-buying in the respective countries (Stokes 2005).

This concern has led scholars to consider asking sensitive questions in an indirect fashion using an unobtrusive measurement technique known as the list experiment (Kuklinski et al. 1997). In a list experiment, the survey sample is randomly split into control and treatment groups. The respondents in the control group receive a list of $J$ non-sensitive yes/no items, and are asked only how many of the items they would respond in the affirmative. The respondents in the treatment group, meanwhile, receive the same list as the control group plus the sensitive item that the analyst wants to measure, and are asked, similarly, how many of the $J+l$ items they would respond in the affirmative. The premise of list experiments is that since respondents have to tell only how many of the items they would respond in the affirmative, no one can know whether a treatment group respondent's answer included the sensitive item. This anonymity, in turn, should encourage a truthful response, and difference-in-means tests can be used to estimate the prevalence of the sensitive behavior/opinion in the sample. In political science, list experiments have been employed to study racial attitudes (Kuklinski et al. 1997), attitudes toward immigrants (Sniderman and Hagendoorn 2007), self-reported voter turnout (Holbrook and Krosnick 2010), and most recently, vote-buying (Corstange 2012; Gonzalez-Ocantos et al. 2012).

Despite the usefulness of list experiments in reducing social desirability pressure, an important limitation of the approach in its original design is that it is not conducive to exploring the relationship between respondents' characteristics and their answers to sensitive items via 
multivariate analyses (Corstange 2009; Blair and Imai 2012). The difference in mean responses between the treatment and control groups are useful only for estimating the proportion of respondents in the sample who answer the sensitive item affirmatively. Strictly speaking, the prevalence of the sensitive behavior/opinion across different sub-groups of the sample can be estimated by repeatedly splitting the sample and running difference-in-means tests between the resulting sub-groups. This approach, however, quickly encounters degrees of freedom constraints and leads to large uncertainty around the point estimates for each sub-group (Corstange 2009).

This shortcoming of the list experiment method is illustrated by the recent study of Gonzalez-Ocantos et al. (2012). In this innovative study, the authors investigate the prevalence of vote-buying in Nicaragua using a list experiment. Startlingly, while only $2 \%$ of the registered voters report being offered a gift or service in exchange for votes when asked directly, the list experiment suggests that in fact nearly a quarter of respondents were targeted. Beyond this aggregate inference, the authors are also interested in the individual-level characteristics (e.g., partisanship, education, income) that might be associated with being targeted for vote-buying. For this purpose they divide their sample along different variables of interest, and run differencein-means tests and linear regressions with interaction terms across the resulting sub-groups. At this point the limitation of the list experiment method becomes apparent. Contrary to the entire body of existing literature and conventional wisdom, the analysis suggests that while partisanship and income have no effect on the likelihood of exposure to vote-buying, the moreeducated are more likely to be targeted. Surprisingly, while the list experiment estimate of the prevalence of vote-buying among respondents with no formal education is $16 \%$, the same figure for college graduates is $37 \%$ - a result difficult to explain. 
Looking at the analysis of Gonzalez-Ocantos et al. (2012) more closely, the limitation of their approach is that dividing the sample into several sub-groups significantly reduces the number of observations in each sub-group, leading to large standard errors that distort the inferential analysis (Gallego and Wantchekon 2012). Therefore, almost all of the sub-group comparisons they investigate result either in a null finding (e.g., partisanship, income) or in a statistically weak result that contradicts conventional wisdom (e.g., education). The low statistical power of this approach severely limits drawing conclusions about the differences in the prevalence of vote-buying across sub-groups of the sample.

This shortcoming of the list experiment method is especially unfortunate for studying vote-buying, because the question of what types of individuals are being targeted is as important as the prevalence of the practice. From a policy perspective, understanding the dynamics of votebuying is essential if we are going to address the phenomenon to improve the accountability of elections in developing democracies. This, in turn, hinges on specifying the determinants of individual behavior. Theoretical and empirical studies to date point to two principal factors: poverty and partisanship (Stokes 2007b). In terms of poverty, the conventional wisdom in the literature is that parties should target impoverished, socio-economically vulnerable individuals because they are more receptive to direct, clientelistic exchanges than programmatic policy appeals, and buying their votes is less costly than buying votes of their wealthier counterparts (Dixit and Londregan 1996; Kitschelt 2000).

In terms of partisanship there is a lively debate about whether a party should go after its core supporters or after individuals who are indifferent or slightly inclined/opposed to the party, i.e., swing voters (Stokes 2005, 2007b; Cox 2009). The driving ideas behind the "core voter models" are risk aversion (Cox and McCubbins 1986), mobilization (Nichter 2008), the 
endogeneity of partisan loyalties to material inducements (Diaz-Cayeros et al. 2012), and the rent-seeking behavior of party brokers (Stokes et al. 2013). A second set of models that are pioneered by Lindbeck and Weibull (1986) and Dixit and Londregan (1996), on the other hand, rests on the intuition that transfers to voters who strongly favor or oppose a particular party are unlikely to make a difference, and thus the best strategy for dispensing material benefits is targeting swing voters. Empirical studies to date paint a mixed picture such that we have results in both directions (Stokes 2007b; Cox 2009). The difficulties associated with attaining a reliable diagnosis of the target individuals most likely have a role in the mixed results. Accordingly, a procedure that allows individual-level multivariate analysis of list experiment data would greatly facilitate adjudicating between competing hypotheses on who gets targeted for vote-buying.

\section{A Modified Design of the List Experiment}

Corstange (2009) developed a revised procedure and statistical estimator called LISTIT that enable researchers to undertake individual-level multivariate analysis on data generated by a list experiment. In this modified design respondents in the control group receive the full list of items (i.e., $J+1$ items that consist of $J$ non-sensitive and one sensitive item), and are asked to evaluate each of the list items individually. There is no change in the procedure for the treatment group. The intuition for this approach is that we can treat the "yes" count of each treatment group respondent as if it were a binomial process with a known average probability for $J+1$ items but unknown individual item probabilities of responding affirmatively. By asking each of the list items individually to control group respondents, on the other hand, we can estimate the individual probabilities of the $J$ non-sensitive items using a set of covariates. In turn, these estimates are applied to the values of their corresponding covariates among the treatment group respondents. Since we already know the average probability of responding affirmatively to $J+1$ 
items for each treatment group respondent, the estimated probabilities of the $J$ non-sensitive items enable us to estimate the probability of responding affirmatively to the sensitive item as well. ${ }^{3}$

This modified design of the list experiment enables us to test hypotheses on the relationship between individual characteristics and the likelihood of being targeted for votebuying. In line with the existing theoretical and empirical literature, our analysis focuses on indicators of partisanship and socio-economic vulnerability. Specifically, we will test whether there is a difference in the likelihood of being targeted between the partisans of different political parties (and nonpartisans), and whether socio-economically vulnerable individuals are more likely to be targeted. We will employ a number of measures for socio-economic vulnerability (i.e., education, wealth, unemployment) to investigate which aspect(s) of this condition are correlated with vote-buying, if at all.

Accordingly, we conducted this modified design of the list experiment as follows. After splitting the sample randomly into treatment and control groups, respondents in the control group were read the following prompt and the list of options:

"People decide who to vote for based on a lot of different reasons. Now I will read you some of the reasons people have told us: Please tell me if they influenced your decision to vote for the party that you have voted.

${ }^{3}$ Blair and Imai (2012) propose multivariate regression estimators for analyzing list experiment data as well. The main difference between their maximum likelihood estimator and LISTIT is that they derive the exact likelihood function while LISTIT uses an approximation. Accordingly, the Blair and Imai estimator is expected to exhibit better statistical properties, especially when the sample size is small. A Monte Carlo simulation study reported in Blair and Imai (2012, 6263), however, shows that the performance of the estimators is indistinguishable in terms of bias and root mean squared error (RMSE) when the sample size is as large as 1,500. Our sample size is larger than 1,500, and therefore we do not anticipate any additional bias or efficiency-loss associated with using LISTIT. We could not implement the procedure of Blair and Imai with our data due to non-convergence of their algorithm. 
- You read newspaper coverage of the campaign regularly

- You read the documents of political parties that included campaign promises

- Someone offered you or your family personal services, a job, or similar material benefits in exchange of your vote for a party

- You and your friends discussed the election campaign and party leaders."

While respondents in the treatment group were presented with the same list, they were specifically instructed to tell only how many of the items have influenced their decision to vote. The prompt for the treatment group read as follows:

"People decide who to vote for based on a lot of different reasons. Now I will read you some of the reasons people have told us. Please do not tell me which of the following have influenced your vote decision. Please just tell me how many of the following have influenced your decision to vote for the party that you have voted."

There are some differences between the wording of our sensitive item (in italics) and the ones used in previous studies on vote-buying that employed a list experiment. In Corstange (2012), for example, the sensitive item reads as follows: "Someone offered you or a relative personal services, a job, or something similar." In this wording it is not explicit that the offer is made in return for the vote of the respondent. The quid pro quo nature of vote-buying is not signaled clearly, and thus those who give affirmative answer to this question might actually be reporting an ordinary campaign promise. In our wording the qualification "in exchange of your vote for a party" highlights the quid pro quo nature of the vote-buying transaction (Stokes 2007b). Thus we explicitly set the context of vote-buying by clearly delineating the transaction in question as an offer of exchange of material benefits for a vote. 
Lastly, Blair and Imai (2012) note that researchers who employ the list experiment technique typically assume that the inclusion of the sensitive item to the list of options has no effect on respondents' answers to control items. They stress that the validity of a list experiment critically depends on this assumption of no design effect. The presence of a "design effect" would suggest that a respondent's evaluation of the control items depends on the sensitive item, leading to different propensities to answer control items affirmatively across the control and treatment groups. In turn, they devise a statistical test with the null hypothesis of no design effect. We implement this test, and fail to reject the null hypothesis of no design effect.

\section{Empirical Context and Analysis}

Turkey with a long electoral experience in competitive multi-party elections since 1946 provides a good setting in which to study vote-buying. ${ }^{4}$ There is a voluminous literature on the prevalence and significance of clientelism and patronage in Turkish politics that dates back to 1970s (Sayarı 1977; Heper and Keyman 1998; Kemahlığlu 2012). The general disposition of the literature is that with the establishment of a competitive party system in 1946 the historical dependency of the periphery on the center in Turkish politics has resulted in enduring patron-client relationships (Güneş-Ayata 1994). Later, when massive urbanization led to new migrant communities in cities clientelistic brokerage between political parties and these communities have become the basis of political mobilization. The empirical contribution of this literature, however, has been quite modest, and individual-level systematic evidence for clientelistic linkages is yet not available.

Another attractive feature of the Turkish context is that the factors identified in the literature as the bases of parties' targeting strategies for clientelism (i.e., partisanship and socioeconomic conditions) have become increasingly important in the voting decisions of the

\footnotetext{
${ }^{4}$ See Çarkoğlu (2012a) for review of elections and voting behavior in Turkey.
} 
electorate during the last decade. A rising influence of party identification is noticeable as a relatively stable period develops in the country with the same party (AKP) winning three consecutive elections (Kalaycioğlu 2008; Çarkoğlu 2012b). The other element that strongly shapes voting behavior is short-term economic evaluations (Çarkoğlu 2012b). The salience of economic conditions coupled with relatively widespread poverty suggests that targeting socioeconomically vulnerable groups even with minor rewards might result in sizable electoral returns. ${ }^{5}$ These two observations suggest that the factors that shape parties' clientelistic strategies are very relevant for the Turkish electoral context.

Remaining more than a decade in power as of 2013, the incumbent AKP is wellpositioned for implementing clientelistic strategies efficiently given its elaborate organizational network and access to public resources. Stokes (2005) notes that a tentacle-like, bottom-heavy, and decentralized organizational structure is a great asset for parties that aim to use minor payoffs to sway voters. In the Turkish context we know that the party with the organizational structure most like that of a political machine is the AKP. ${ }^{6}$ The perception that the prevalence of clientelism and vote-buying distorts Turkish democracy is widespread among the scholars and politicians alike. While Öniş $(2009,24$, ft.2) considers "the distribution of food and coal to actual and potential supporters of the party on a selective basis" as an important element of AKP's

\footnotetext{
${ }^{5}$ Official figures show that $18 \%$ of the Turkish population lives below the national poverty line as of 2009.

${ }^{6}$ See Sayar1 (2012). According to the Chief Public Prosecutor's Office, as of January 2013 AKP has 7,551,472 registered members, followed by CHP with 953,416 members, and MHP with 363,393 members. While one might be skeptical about the substantive meaning of political party membership in the Turkish context, the sheer discrepancy in the membership numbers between AKP and other parties constitutes yet another indication of AKP's large organizational network.
} 
social policy, the leader of the main opposition party CHP openly accused AKP of vote-buying ahead of the 2009 local elections, and appealed to public prosecutors to take action. ${ }^{7}$

Accordingly, our study constitutes the first systematic treatment of the prevalence of vote-buying in Turkey. We embedded our list experiment into a nationally representative faceto-face survey conducted between July 21 and August 26, 2011, two weeks after the parliamentary elections. ${ }^{8}$ The sampling procedure starts with the use of Turkish Statistical Institute's (TUIK) NUTS-2 regions. The target sample was distributed according to each region's share of urban and rural population in accordance with the Address Based Population Registration System (ADNKS) records as of the end of 2010. Next, TUIK's block data were used with block size set at 400 residents. Probability proportionate to size (PPS) sampling was used in distributing the blocks to NUTS-2 regions. The individual to be interviewed in each household was selected using a lottery method on the basis of reported target population of 18 years or older in the household. ${ }^{9}$

We first use the list experiment data to estimate the proportion of individuals targeted for vote-buying. When asked directly, $16.2 \%$ of our respondents admitted being offered a material benefit in exchange for vote for a party (Table 1, column 1). ${ }^{10}$ In order to compare this figure with what people reported when asked indirectly, we momentarily set aside the control group

\footnotetext{
${ }^{7}$ See http://www.cnnturk.com/2008/turkiye/12/11/baykaldan.komur.dagitimi.yorumu.suctur/504324.0/index.html. ${ }^{8}$ The Turkish Election Survey (TES) is generously funded by the Scientific and Technological Research Council of Turkey (TUBITAK), the Open Society Institute - Turkey, the Halle Institute - Emory University, and Koç University. The interviews were conducted by Infakto Research Workshop (http://www.infakto.com.tr).

${ }^{9}$ If for any reason that individual could not respond to our questions in our first visit, then the same household was visited up to three times until a successful interview was conducted. If after three trials the interview could not be conducted, then this particular household was dropped from the sample as incomplete interview, and no substitution was applied.

${ }^{10}$ Comparing this figure with reports from the other developing countries presented in Figure 1, we see that Turkey would be just at the median in terms of the prevalence of vote-buying.
} 
respondents' (direct) answers to the sensitive question, and add up their responses to the three non-sensitive items. Then we compare the average of this sum in the control group with the average count in the treatment group on the full list of four items. The mean number of items reported by respondents in the control group with only three options is 1.01 , while the mean in the treatment group with four options is 1.36 (Table 1, column 2). Thus, the estimated proportion of individuals targeted for vote-buying according to the list experiment is $35.3 \% .{ }^{11}$ When we acknowledge the sensitivity of the question and try to minimize the associated social desirability bias by asking it indirectly, the proportion of individuals who report being targeted for votebuying is more than double of what people would admit when asked directly. This striking difference highlights the value of the list experiment technique and the extent to which traditional obtrusive measures of vote-buying underreport its prevalence.

\section{[TABLE 1 ABOUT HERE]}

Beyond this aggregate inference on the prevalence of vote-buying, we are also interested in the types of individuals who are being targeted. As a first step, in Table 2 we divide our sample across some key variables related to socio-economic vulnerability and partisanship. ${ }^{12}$ Column 3 of Table 2 presents the proportion of each sub-group in our sample, and Column 4 reports the proportion of individuals within each sub-group that admit being targeted when asked directly. The corresponding list experiment estimates for each sub-group are given in Column 5. To construct our partisanship variables, we asked our respondents whether they thought of

${ }^{11}$ The difference in group averages falls between zero and one, and it represents the proportion of treatment group respondents that (indirectly) answered affirmatively to the sensitive votebuying question. The difference we report is statistically significant at $p<.01$.

${ }^{12}$ Here we follow the practice of Gonzalez-Ocantos et al. (2012). 
themselves "as close to any particular party." Respondents who answered affirmatively were asked to give the name of the party they felt close, and were identified as partisans of that party. Nonpartisans are those who did not think of themselves as close to any particular party. In the analysis we include the partisans of the incumbent AKP and of the three major opposition parties (CHP, MHP, and BDP) that won seats in the parliament. ${ }^{13}$ Additionally, the large number of AKP partisans in the sample allows us to further distinguish between strong and weak partisans of the party - strong AKP partisans are those who felt "very close" to AKP while the remaining AKP partisans are identified as weak partisans. Descriptions of the other variables employed in the analysis and summary statistics are presented in Table 3.

[TABLE 2 ABOUT HERE]

[TABLE 3 ABOUT HERE]

Examining Table 2, two observations stand out. First, across most sub-groups the proportion of individuals that report being targeted for vote-buying increases substantially when asked indirectly instead of directly. Crucially however, the list experiment estimates have large standard errors that render inference on the differences between sub-groups difficult. Figure 2 plots estimates of the prevalence of vote-buying for different sub-groups together with $95 \%$ confidence intervals, and we see that across all the variables none of the sub-group estimates are statistically different from each other. For example, while the point estimates for different partisan sub-groups vary considerably (e.g., 47.1\% for “Strong AKP Partisans" versus 19.6\% for

${ }^{13}$ In the 2011 parliamentary elections AKP won 327 seats in the 550-seat parliament, followed by the 135 seats of CHP (Cumhuriyet Halk Partisi), 53 seats of MHP (Milliyetçi Hareket Partisi), 29 seats of BDP (Barlş ve Demokrasi Partisi), and 6 seats belonging to independent candidates. 
"CHP Partisans"), the size of the standard errors suggests that there is no statistical difference between them. These results are similar to those reported in Gonzalez-Ocantos et al. (2012) in the sense that dividing the sample along variables of interest significantly reduces the number of observations within each sub-group, and leads to large standard errors that limit inference.

\section{[FIGURE 2 ABOUT HERE]}

The preceding analysis confirms that the strategy of running difference-in-means tests across different sub-groups of the sample is not a satisfactory approach to address the question of what types of individuals are being targeted for vote-buying. ${ }^{14}$ Accordingly, we need an approach that uses data more efficiently, and for this purpose we utilize the statistical estimator LISTIT developed by Corstange (2009) to conduct individual-level multivariate analysis of list experiment data. ${ }^{15}$ Again our interest lies in indicators of socio-economic vulnerability and partisanship, and we use the same set of variables used to construct the sub-groups.

\footnotetext{
${ }^{14}$ Another approach to list experiment data is to run linear regression with interaction terms where the treatment group count serves as the dependent variable (Holbrook and Krosnick 2010; Gonzalez-Ocantos et al. 2012). In this approach a dummy variable indicating treatment condition is included in the regression together with all the explanatory variables and their interactions with the treatment condition. These interactions test whether differences in the reported number of list items between the two conditions is larger in some sub-groups than others while controlling for the overlap among the different sub-groups. Blair and Imai (2012) note that this approach is prone to bias, and often results in negative predicted values for the prevalence of the sensitive behavior when affirmative responses are rare. Nevertheless, we perform this analysis as well, and do not find any statistically significant differences in the estimated prevalence of votebuying across the sub-groups.

${ }^{15}$ The implementation of Corstange's (2009) procedure necessitates selection of explanatory variables for the non-sensitive items in the list experiment. Specifically, the probability of answering "yes" to each non-sensitive item is assumed to be distributed logistically according to some set of covariates. Corstange $(2009,59)$ notes that "future research on the list experiment should include an examination of the effects of differing model specifications for the nonsensitive items on estimates returned on the sensitive item." In our case different model
} 
In Table 4 we report our results in two columns: the first column presents estimates from a standard logistic regression with response to the direct question of whether the respondent was targeted for vote-buying as the dependent variable, and the second column reports estimates from the list experiment using the LISTIT estimator. As we can see in the first column, none of the coefficients of the indicators of partisanship and socio-economic vulnerability are statistically significant. Thus, ignoring the consequences of social desirability bias would lead to the conclusion that partisanship and socio-economic vulnerability do not have an effect on the likelihood of being targeted for vote-buying.

\section{[TABLE 4 ABOUT HERE]}

When we account for the sensitivity of the question using the list experiment, however, we obtain some important results as reported in the second column of Table 4. We should note that the estimates presented in the second column are logit coefficients that would be returned if we had asked the sensitive item directly as a yes/no question, and respondents had not misrepresented their answers (Corstange 2009). First, we see that strong AKP partisanship is a statistically significant predictor of being targeted for vote-buying. ${ }^{16}$ Beyond statistical significance, there is a ten-fold increase in this coefficient when we ask the sensitive question indirectly rather than directly. This result provides support for the "core voter" hypotheses in the literature as the incumbent AKP seems to target individuals who identify themselves very closely

specifications for the non-sensitive items resulted in substantively similar estimates on the sensitive item.

${ }^{16}$ The estimate for strong AKP partisanship is significant at $p<0.1$ only, yet this is expected as "large standard errors are simply the cost of doing business when the question is sensitive" (Corstange 2009, 62). 
with the party, and not its weak partisans or individuals who do not identify themselves with any party. ${ }^{17}$

Second, while none of our indicators of socio-economic vulnerability were statistically significant when asked directly, using the indirect method we see that the level of education is a strong predictor of being targeted for vote-buying. Specifically, less-educated people are more likely to be the targets of such efforts. The significance of the level of education despite the insignificance of wealth is interesting. Voter compliance is critical for vote-buying arrangements (Stokes 2005), and it might be the case that less-educated people are relatively easier to monitor, or are relatively more afraid by the 'punishment' that a political broker can inflict upon in case of non-compliance. ${ }^{18}$ Another potential explanation is that education is a good proxy for socioeconomic vulnerability in developing countries. Finally, vote-buying efforts seem to be concentrated in urban areas while no such inference was possible in the direct question model. This result is compatible with the existing literature hinting that the primary locus of clientelist exchanges in the Turkish context is the newly-urbanized migrant communities in cities (GüneşAyata 1994).

${ }^{17}$ This finding stands in contrast to the null results reported in Gonzalez-Ocantos et al. (2012) regarding the effect of partisanship. As we have argued before, one explanation for this observation is the low statistical power of the approach taken in Gonzalez-Ocantos et al. (2012) dividing the sample into several sub-groups leads to large standard errors that limit inference on sub-group comparisons. An alternative explanation is the difference between the number of political parties in Nicaragua and Turkey that can engage in vote-buying in an efficient and extensive manner. Gonzalez-Ocantos et al. (2012: 207) emphasize that in Nicaragua "parties on the left and right have resources to develop and maintain clientelistic networks. In the context of the 2008 elections, both sides could engage in vote-buying." In contrast, in Turkey only the incumbent party AKP has the resources to operate an efficient political machine. This divergent political context between Nicaragua and Turkey in terms of the number of machines engaging in clientelism might be a factor in explaining different results regarding the effect of partisanship. ${ }^{18}$ Gonzalez-Ocantos et al. (2012) provide evidence on the importance of monitoring by parties for vote-buying. 
Figure 3 illustrates the value of our approach in a graphical form by comparing the estimated probabilities of being targeted for vote-buying for different values of the key variables across the logit (asking directly) and LISTIT (asking indirectly) estimations. In the left panel we see the impact of education on the likelihood of being targeted for a non-partisan, employed, non-Kurdish speaking urban resident with an average level of wealth. While education has no discernible effect on the likelihood of being targeted when respondents are asked directly, we see a strong negative effect when we account for the sensitivity of the question using the list experiment. The estimated probability of being targeted is around $40 \%$ for a primary school graduate (5 years of education), yet it rapidly falls to $7 \%$ for a high school graduate (11 years of education), and to just $2 \%$ for a college graduate (15 years of education). The very strong effect exerted by AKP partisanship on the likelihood of being targeted is apparent in the center panel: In the LISTIT estimation while the estimated probability for a non-partisan, employed, nonKurdish speaking urban dweller with an average level of wealth and education (7.5 years) is $21 \%$, it jumps to $75 \%$ for a strong AKP partisan with otherwise identical characteristics. Finally, the right panel shows that vote-buying in Turkey occurs in urban settings - another inference that we could not have made if we had asked our respondents directly.

[FIGURE 3 ABOUT HERE]

\section{Implications and Discussion}

Scholarly accounts of vote-buying hint that "a blossoming market for votes has emerged as an epiphenomenon of democratization" (Schaffer 2007, 1), yet studying vote markets systematically has been difficult due to the sensitive nature of the topic. We tried to overcome this problem by 
using an unobtrusive measurement technique, the list experiment, which offers respondents a relatively high degree of anonymity. Our list experiment provides the first systematic evidence of the prevalence of vote-buying efforts in Turkey, a major developing democracy. The openly revealed prevalence of vote-buying in Turkey stands at the median (about 16\%) of vote-buying estimates reported in the literature from developing democracies. However, once we neutralize the sensitivity of the subject through the list experiment technique, the prevalence of vote-buying reaches quite significant levels at about $35 \%$. In other words, one in every three voting age citizens in the country appears to be targeted.

This high level of vote-buying activity constitutes important evidence on the pervasiveness of clientelistic electoral linkages in the developing world (Kitschelt 2000), which has ominous theoretical and practical implications for the practice of democracy. From a theoretical perspective, one of the central normative appeals of democracy is that citizens have equal political rights as well as a certain degree of autonomy as voters (Stokes et al. 2013). Votebuying, however, precludes certain voters (almost always the socio-economically vulnerable) from revealing their policy preferences in elections (Hasen 2000). Effectively, "a subset of the citizenry is deprived of effective participation in collective decisions to which they will be subject" (Stokes 2007a, 90). Thus, the equality of political rights no longer exists in practice, and one of the fundamental tenets of democracy, articulated as the equal consideration principle in elections by Robert Dahl, has been breached. (Dahl 1987; Stokes 2007a).

The practical implications of a high level of vote-buying for the quality of democratic processes are equally worrisome. As noted by Schaffer (2007), the need to fund vote-buying activities might result in the criminalization of politics. In line with this prediction and the high level of vote-buying activities that we report in Turkey, in a recent graft probe involving several 
ministers of the AKP government prosecutors accused suspects of improperly awarding construction permits to certain developers and overlooking violations of construction regulations. ${ }^{19}$ Earlier it was reported that one developer mentioned in the graft probe had donated 40 thousand food packages to AKP for distribution. ${ }^{20}$ As the opposition parties do not have access to such resources, the prevalence of vote-buying generates an unfair advantage for the incumbent AKP to sustain its electoral hegemony and establish itself as a dominant party. ${ }^{21}$ The loss of transparency in public spending during the AKP rule is striking as well: The public procurement law has been changed dozens of times, each time exempting more public agencies from the supervision of the Public Procurement Authority, and the ability of the Court of Accounts to audit public spending has been severely restricted. ${ }^{22}$

We also provide strong evidence on the question of what types of individuals are targeted for vote-buying. Our findings represent a unique contribution to the literature as we draw on original, individual-level data that has been collected in an unobtrusive manner in a large, developing democracy. We find that in the Turkish case strong partisans of the ruling AKP, lesseducated individuals, and urban residents are significantly more likely to be targeted. In terms of partisanship, our results support the hypothesis that parties target their core supporters rather than swing voters. While Cox and McCubbins (1986) emphasize the role of risk aversion for this strategy, other mechanisms have been offered in the literature as well: Nichter (2008), for example, argues that targeting core supporters aim at boosting turnout whereas Diaz-Cayeros et

\footnotetext{
${ }^{19}$ See http://tinyurl.com/p9gvjks

${ }^{20}$ See http://tinyurl.com/mwgmeny

${ }^{21}$ Many analysts consider the continuing electoral hegemony of AKP as a sign of the emergence of a dominant party system in Turkey. For more on this, see Çarkoğlu (2011), Müftüler-Baç and Keyman (2012), and Gümüşçü (2013). In addition, Aytaç (2013) presents evidence on the strategic targeting of public benefits at the district-level as well.

${ }^{22}$ On the public procurement law, see http://tinyurl.com/m7muf $2 \mathrm{w}$. On Court of Accounts, see http://tinyurl.com/qy7ppvf.
} 
al. $(2012,23)$ emphasize that politicians funnel benefits to their core voters to "take care of their own." More recently, Stokes et al. (2013) brought a different perspective to the debate by suggesting that core supporters are targeted not for their votes or turnout but for their involvement in party brokers' networks. Further research is needed to adjudicate between these mechanisms.

In addition, our results suggest that the education level of an individual is a better predictor of whether she will be targeted for vote-buying than her wealth. Speculatively, a low level of education might put individuals into networks that are easier to monitor by party brokers or they might feel more vulnerable to potential backlash from a broker in case of non-compliance to the vote-buying arrangement. In the Turkish case vote-buying activities appear to take place predominantly in the urban communities, which resonates well with the existing literature. In rural communities clientelistic exchanges might have different forms like targeted subsidies, as previously reported (Gürkan and Kasnakoğlu 1991).

Finally, from a research design perspective our study illustrates the value of combining different methodological innovations to answer substantively important questions. A list experiment is a useful tool for ameliorating the measurement error associated with social desirability bias when diagnosing the overall prevalence of a sensitive behavior. However, most often researchers are also interested in the behavior's individual-level predictors. The list experiment technique in its original form fails to produce satisfactory results to address this question due to data analysis limitations (Corstange 2009). By combining this technique with a statistical estimator that allows multivariate analysis on list experiment data in an efficient manner, we have been able to estimate the overall prevalence of the sensitive behavior and identify the types of individuals who are more likely to engage in such behavior. 


\section{References}

Aytaç, S. E. (2013). Distributive Politics in a Multiparty System: The Conditional Cash Transfer Program in Turkey. Comparative Political Studies, Prepublished on July 24, 2013, DOI: $10.1177 / 0010414013495357$.

Blair, G., \& Imai, K. (2012). Statistical Analysis of List Experiments. Political Analysis, 20(1), 47-77.

Bradburn, N. M., Sudman S., Blair, E., \& Stocking, C. (1978). Question Threat and Response Bias. Public Opinion Quarterly, 42(2), 221-234.

Brusco, V., Nazareno, M., \& Stokes, S. C. (2004). Vote-buying in Argentina. Latin American Research Review, 39(2), 66-88.

Corstange, D. (2009). Sensitive Questions, Truthful Answers? Modeling the List Experiment with LISTIT. Political Analysis, 17(1), 45-63.

Corstange, D. (2012). Vote Trafficking in Lebanon. International Journal of Middle East Studies, 44(3), 483-505.

Cox, G. W. (2009). Swing Voters, Core Voters, and Distributive Politics. In I. Shapiro, S. C. Stokes, E. J. Wood, \& A. S. Kirshner (Eds.), Political Representation (pp. 342-357). New York: Cambridge University Press.

Cox, G. W., \& McCubbins, M. D. (1986). Electoral Politics as a Redistributive Game. Journal of Politics, 48(2), 370-389.

Çarkoğlu, A. (2011). Turkey’s 2011 General Elections: Toward a Dominant Party System? Insight Turkey, 13(3), 43-62.

Çarkoğlu, A. (2012a). Voting Behavior. In M. Heper, \& S. Sayarı (Eds.), The Routledge Handbook of Modern Turkey (pp. 160-170). London: Routledge. 
Çarkoğlu, A. (2012b). Economic Evaluations vs. Ideology: Diagnosing the Sources of Electoral Change in Turkey, 2002 - 2011. Electoral Studies, 31, 513-521.

Dahl, R. (1987). Democracy and Its Critics. New Haven: Yale University Press.

Desposato, S. W. (2007). How does vote-buying shape the legislative arena? In F. C. Shaffer (Ed.), Elections for Sale: The Causes and Consequences of Vote-buying (pp. 101-122). Boulder, CO: Lynne Rienner Publishers.

Diaz-Cayeros, A., Estevez, F., \& Magaloni, B. (2012). Strategies of Vote-buying: Democracy, Clientelism, and Poverty Relief in Mexico. Unpublished manuscript. Stanford University.

Dixit, A., \& Londregan, J. (1996). The Determinants of Success of Special Interests in Redistributive Politics. Journal of Politics, 58(4), 1132-1155.

Gallego, J., \& Wantchekon, L. (2012). Experiments on Clientelism and Vote-Buying. In D. Serra, \& L. Wantchekon (Eds.), New Advances in Experimental Research on Corruption (pp. 177-212). Bingley: Emerald Group Publishing.

Gonzalez-Ocantos, E., de Jonge, C. K., Meléndez, C., Osorio, J., \& Nickerson, D. W. (2012). Vote-buying and Social Desirability Bias: Experimental Evidence from Nicaragua. American Journal of Political Science, 56(1), 202-217.

Gümüşüü, Ş. (2013). The Emerging Predominant Party System in Turkey. Government and Opposition, 48(2), 223-244.

Güneş-Ayata, A. (1994). Roots and Trends of Clientelism in Turkey. In L. Roniger, \& A. Güneş-Ayata (Eds.), Democracy, Clientelism, and Civil Society (pp. 49-63). Boulder: Lynne Rienner Publishers.

Gürkan, A. A. \& Kasnakoğlu, H. (1991). The Political Economics of Agricultural Price Support in Turkey: An Empirical Assessment. Public Choice, 70: 277-298. 
Hasen, R. L. (2000). Vote Buying. California Law Review, 88(5), 1323-1371.

Heper, M., \& Keyman, E. F. (1998). Double-faced State: Political Patronage and the Consolidation of Democracy in Turkey. Middle Eastern Studies, 34(4), 259-277.

Holbrook, A. L., \& Krosnick, J. A. (2010). Social Desirability Bias in Voter Turnout Reports: Tests Using the Item Count Technique. Public Opinion Quarterly, 74(1), 37-67.

Kalaycioğlu, E. (2008). Attitudinal Orientation to Party Organizations in Turkey in the 2000s. Turkish Studies, 9(2), 297-316.

Kemahlığlu, Ö. (2012). Agents or Bosses? Patronage and Intra-Party Politics in Argentina and Turkey. Colchester, UK: ECPR Press.

Kitschelt, H. (2000). Linkages between Citizens and Politicians in Democratic Polities. Comparative Political Studies, 33(6-7), 845-879.

Kuklinski, J. H., Cobb, M. D., \& Gilens, M. (1997). Racial Attitudes and the "New South". Journal of Politics, 59(2), 323-349.

Lindbeck, A., \& Weibull, J. W. (1987.) Balanced Budget Redistribution as the Outcome of Political Competition. Public Choice, 52(3), 273-297.

Müftüler-Baç, M., \& Keyman, E. F. (2012). Turkey Under the AKP: The Era of Dominant-Party Politics. Journal of Democracy, 23(1), 85-99.

Nichter, S. (2008). Vote Buying or Turnout Buying? Machine Politics and the Secret Ballot. American Political Science Review, 102(1), 19-31.

Öniş, Z. (2009). Conservative Globalism at the Crossroads: The Justice and Development Party and the Thorny Path to Democratic Consolidation in Turkey. Mediterranean Politics, 14(1), 21-40. 
Sayarı, S. (1977). Political Patronage in Turkey. In E. Gellner, \& J. Waterbury (Eds.), Patrons and Clients in Mediterranean Societies (pp. 103-113). London: Duckworth.

Sayarı, S. (2012). Political Parties. In M. Heper, \& S. Sayarı (Eds.), The Routledge Handbook of Modern Turkey (pp. 182-193). London: Routledge.

Schaffer, F. C. (2007). Why Study Vote-buying? In F. C. Shaffer (Ed.), Elections for Sale: The Causes and Consequences of Vote-buying (pp. 1-16). Boulder, CO: Lynne Rienner Publishers.

Sniderman, P. M., \& Hagendoorn, A. (2007). When Ways of Life Collide: Multiculturalism and Its Discontents in the Netherlands. Princeton: Princeton University Press.

Stokes, S. C. (2005). Perverse Accountability: A Formal Model of Machine Politics with Evidence from Argentina. American Political Science Review, 99(3), 315-325.

Stokes, S. C. (2007a). Is Vote-buying Undemocratic? In F. C. Shaffer (Ed.), Elections for Sale: The Causes and Consequences of Vote-buying (pp. 81-100). Boulder, CO: Lynne Rienner Publishers.

Stokes, S. C. (2007b). Political Clientelism. In C. Boix, \& S. C. Stokes (Eds.), Oxford Handbook of Comparative Politics (pp. 604-627). New York: Oxford University Press.

Stokes, S. C., Dunning, T., Nazareno, M., \& Brusco, V. (2013). Brokers, Voters, and Clientelism: The Puzzle of Distributive Politics. New York: Cambridge University Press.

Weitz-Shapiro, R. (2012). What Wins Votes: Why Some Politicians Opt Out of Clientelism. American Journal of Political Science, 56(3), 568-583. 


\section{Tables}

Table 1

Aggregate Results on the Prevalence of Vote-buying in Turkey

\section{Asked Directly}

Control

Treatment

Estimated Vote-buying (\%)

\section{List Experiment}

$1.01[1054]$

$1.36[958]$

$16.2(1.9)$
$35.3(6.7)$

Note: Control and treatment values refer to the mean number of items individuals have responded affirmatively in the list experiment. The number of respondents in each condition is given in brackets. Standard errors in parentheses are adjusted for the survey design. 
Table 2

Prevalence of Vote-buying across Sub-groups of the Sample when Asked Directly versus List Experiment Estimates

\begin{tabular}{|c|c|c|c|c|}
\hline & Subgroup & $\begin{array}{c}\text { Sample } \\
\text { Proportion }\end{array}$ & $\begin{array}{c}\text { Asked } \\
\text { Directly }\end{array}$ & $\begin{array}{c}\text { List Experiment } \\
\text { Estimate }\end{array}$ \\
\hline Partisanship & $\begin{array}{l}\text { Strong AKP Partisan } \\
\text { Weak AKP Partisan } \\
\text { CHP Partisan } \\
\text { MHP Partisan } \\
\text { BDP Partisan } \\
\text { Nonpartisan }\end{array}$ & $\begin{array}{c}22.6 \% \\
22.6 \% \\
17.0 \% \\
4.8 \% \\
3.8 \% \\
19.0 \%\end{array}$ & $\begin{array}{c}19.0 \% \\
17.0 \% \\
18.9 \% \\
21.3 \% \\
7.5 \% \\
10.9 \%\end{array}$ & $\begin{array}{l}47.1 \%(13.6) \\
20.8 \%(10.6) \\
19.6 \%(15.1) \\
21.6 \%(26.8) \\
59.3 \%(34.3) \\
38.5 \%(12.1)\end{array}$ \\
\hline Wealth & $\begin{array}{l}1^{\text {st }} \text { (Bottom) Quarter } \\
2^{\text {nd }} \text { Quarter } \\
3^{\text {rd }} \text { Quarter } \\
4^{\text {th }} \text { (Top) Quarter }\end{array}$ & $\begin{array}{l}23.2 \% \\
33.7 \% \\
23.6 \% \\
19.5 \%\end{array}$ & $\begin{array}{l}12.0 \% \\
16.0 \% \\
18.2 \% \\
19.3 \%\end{array}$ & $\begin{array}{l}32.1 \%(10.2) \\
31.7 \%(9.9) \\
48.0 \%(12.5) \\
28.3 \%(13.7)\end{array}$ \\
\hline Education & $\begin{array}{l}\text { No Education } \\
\text { Primary } \\
\text { Secondary } \\
\text { College }\end{array}$ & $\begin{array}{c}11.5 \% \\
52.7 \% \\
26.6 \% \\
9.2 \%\end{array}$ & $\begin{array}{l}6.8 \% \\
17.7 \% \\
16.5 \% \\
19.3 \%\end{array}$ & $\begin{array}{c}27.5 \%(13.2) \\
34.5 \%(8.8) \\
43.0 \%(12.6) \\
8.1 \%(21.4)\end{array}$ \\
\hline Kurdish-Speaking & $\begin{array}{l}\text { Speaks Kurdish } \\
\text { Others }\end{array}$ & $\begin{array}{l}13.3 \% \\
86.7 \%\end{array}$ & $\begin{array}{l}13.5 \% \\
16.7 \%\end{array}$ & $\begin{array}{c}35.2 \%(15.9) \\
34.2 \%(7.2)\end{array}$ \\
\hline Employment & $\begin{array}{l}\text { Unemployed } \\
\text { Others }\end{array}$ & $\begin{array}{c}8.7 \% \\
91.3 \%\end{array}$ & $\begin{array}{l}17.2 \% \\
16.2 \%\end{array}$ & $\begin{array}{c}23.8 \%(20.3) \\
36.4 \%(6.8)\end{array}$ \\
\hline Residence & $\begin{array}{l}\text { Urban } \\
\text { Rural }\end{array}$ & $\begin{array}{l}79.6 \% \\
20.4 \%\end{array}$ & $\begin{array}{l}17.0 \% \\
13.1 \%\end{array}$ & $\begin{array}{c}35.0 \%(7.6) \\
36.8 \%(14.1)\end{array}$ \\
\hline
\end{tabular}

Note: Standard errors in parentheses are adjusted for the survey design. 
Table 3

Summary Statistics and Variable Descriptions

\begin{tabular}{ccccc}
\hline Variable & Mean & St. Dev. & Min. & Max \\
\hline Wealth & 4.44 & 2.38 & 0 & 12 \\
Education & 7.54 & 4.06 & 0 & 15 \\
Kurdish-Speaking & 0.13 & 0.34 & 0 & 1 \\
Unemployed & 0.09 & 0.28 & 0 & 1 \\
Urban Residence & 0.80 & 0.40 & 0 & 1 \\
\hline
\end{tabular}

Note: Variable descriptions are as follows. Wealth: sum of the ownership status $(1=$ yes, $0=$ no $)$ of the following 12 items: landline phone, dishwasher, automatic washing machine, plasma or LCD television, air conditioner in the house, a property that provides rent income, summer house, a private car, mobile phone, credit card, computer, savings account in a bank. Education: number of years of formal education. Kurdish-Speaking: coded 1 for individuals who can speak Kurdish. Employment: coded 1 for individuals who are currently unemployed but are looking for a job. Urban Residence: coded 1 for urban residents. 
Table 4

Determinants of Being Targeted for Vote-buying when Asked Directly (LOGIT) versus List Experiment Results Using LISTIT

\begin{tabular}{|c|c|c|}
\hline VARIABLES & LOGIT & LISTIT \\
\hline Strong AKP Partisan & $\begin{array}{l}0.23 \\
(.33)\end{array}$ & $\begin{array}{l}2.42 * \\
(1.36)\end{array}$ \\
\hline Weak AKP Partisan & $\begin{array}{l}0.09 \\
(.33)\end{array}$ & $\begin{array}{c}-0.91 \\
(.84)\end{array}$ \\
\hline CHP Partisan & $\begin{array}{l}0.10 \\
(.34)\end{array}$ & $\begin{array}{l}-1.18 \\
(1.58)\end{array}$ \\
\hline MHP Partisan & $\begin{array}{l}0.31 \\
(.46)\end{array}$ & $\begin{array}{c}0.44 \\
(1.04)\end{array}$ \\
\hline BDP Partisan & $\begin{array}{c}-0.90 \\
(.67)\end{array}$ & $\begin{array}{l}-0.32 \\
(1.21)\end{array}$ \\
\hline Nonpartisan & $\begin{array}{l}-0.44 \\
(.36)\end{array}$ & $\begin{array}{c}-0.64 \\
(.87)\end{array}$ \\
\hline Wealth & $\begin{array}{l}0.06 \\
(.04)\end{array}$ & $\begin{array}{l}0.21 \\
(.17)\end{array}$ \\
\hline Education & $\begin{array}{l}0.03 \\
(.02)\end{array}$ & $\begin{array}{c}-0.37 * * \\
(.16)\end{array}$ \\
\hline Unemployed & $\begin{array}{l}0.25 \\
(.31)\end{array}$ & $\begin{array}{l}0.81 \\
(.82)\end{array}$ \\
\hline Kurdish-Speaking & $\begin{array}{l}-0.12 \\
(.27)\end{array}$ & $\begin{array}{l}0.22 \\
(.87)\end{array}$ \\
\hline Urban Residence & $\begin{array}{l}0.24 \\
(.24)\end{array}$ & $\begin{array}{c}3.54 * * \\
(1.39)\end{array}$ \\
\hline Intercept & $\begin{array}{c}-2.31 * * * \\
(.39)\end{array}$ & $\begin{array}{c}-2.37 * * \\
(1.15)\end{array}$ \\
\hline $\begin{array}{l}\ln L \\
\mathrm{~N} \text { (Control) } \\
\mathrm{N} \text { (Treatment) }\end{array}$ & $\begin{array}{c}-459.3 \\
1055\end{array}$ & $\begin{array}{c}-3069.1 \\
936 \\
851\end{array}$ \\
\hline
\end{tabular}

Note: Standard errors are in parentheses. $* p<.1, * * p<.05, * * * p<.01$. 


\section{Figures}

Figure 1: Reported Prevalence of Vote-buying Efforts across the Developing World

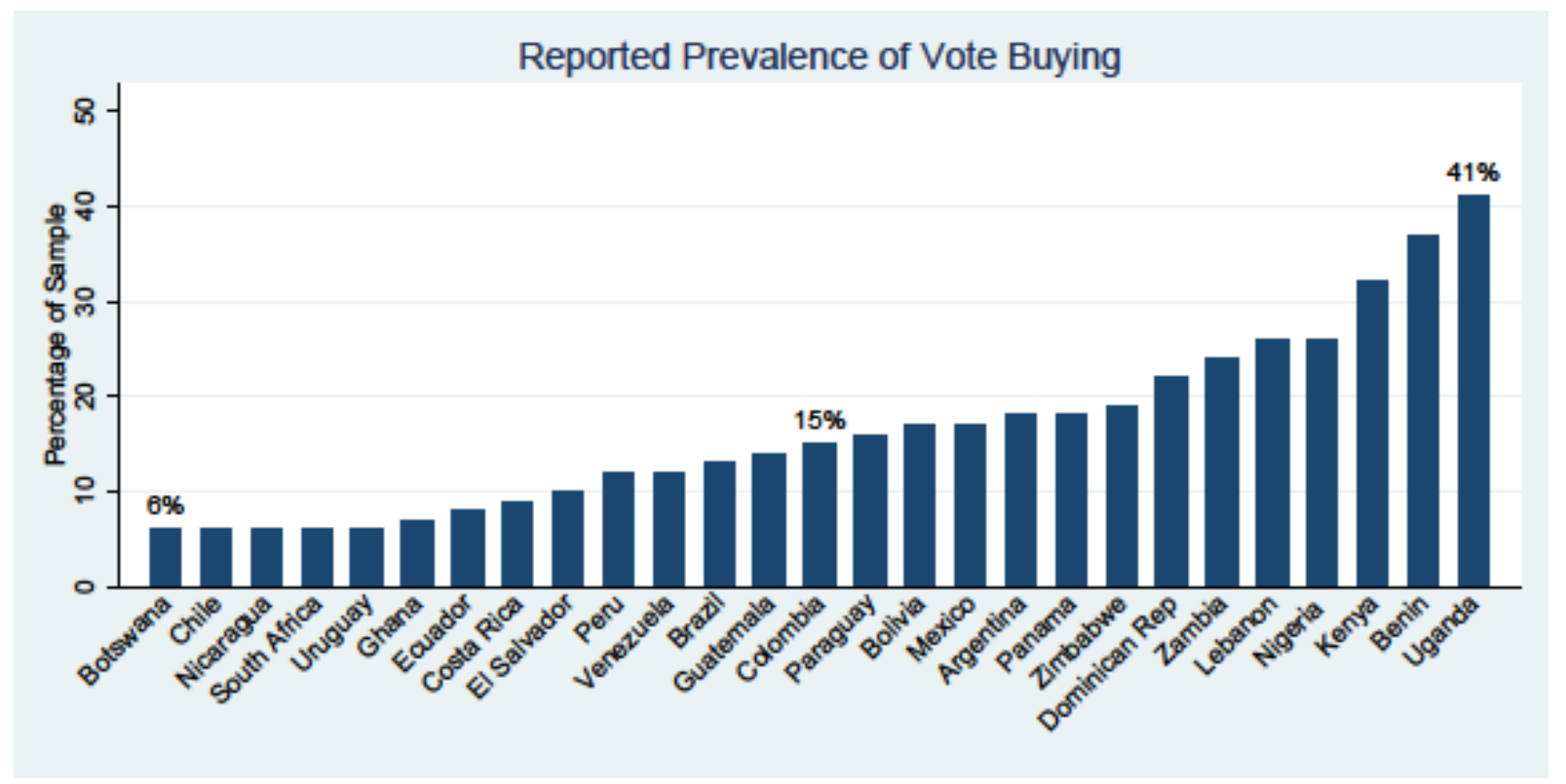

Note. Data for Latin American countries are from Latin American Public Opinion Project (2010). The question is "In recent years and thinking about election campaigns, has a candidate or someone from a political party offered you something like a favor, food, or any other benefit or thing in return for your vote?" and the figures refer to the proportion answered "Sometimes" or "Often." Data for African countries are from Afrobarometer Round 3 (2005-2006) and Round 5 (2011-2012) surveys. The question is "And during the last election in YEAR, how often, if ever, did a candidate or someone from a political party offer you something, like food or a gift or money, in return for your vote?" and the figures refer to the proportion answered "At least once." The estimate for Lebanon is from Corstange (2012) and refers to the proportion of respondents admitting that offers of personal services, a job, or something similar have influenced their votes in the 2009 election. 
Figure 2: Prevalence of Vote-buying According to the List Experiment across Different Sub-groups of the Sample
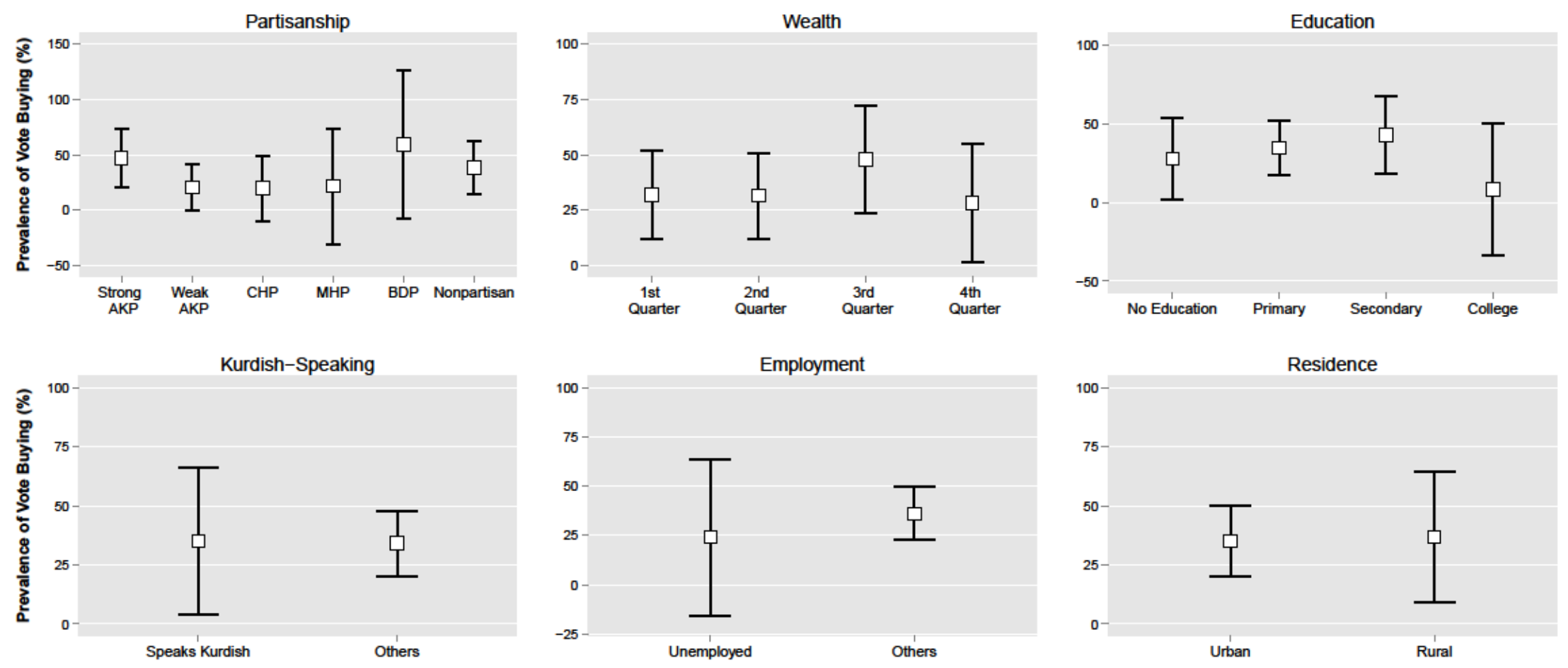

Note: The closed lines represent $95 \%$ confidence intervals around the point estimates. The figure is constructed using list experiment estimates for each sub-group as reported in Table 2. 
Figure 3: Probability of Being Targeted for Vote-buying when Asked Directly (LOGIT) versus List Experiment Results Using LISTIT
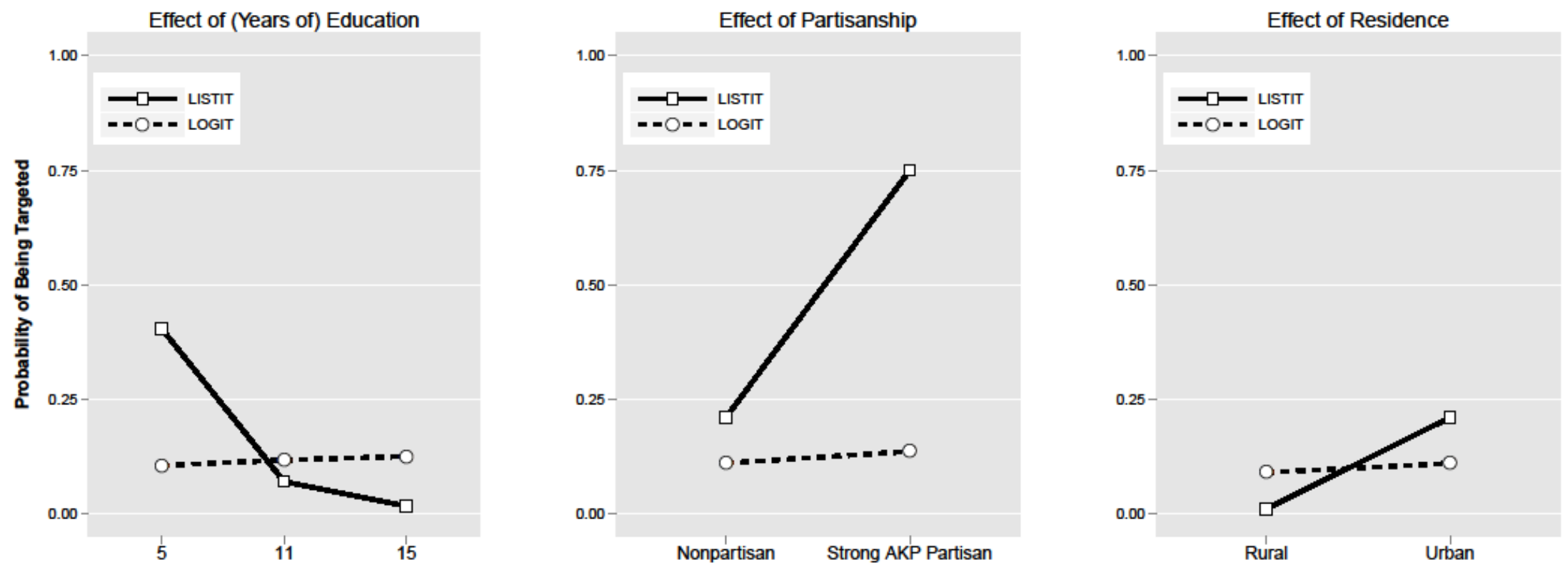

Note: In the left panel the probability of being targeted for vote-buying is calculated for a nonpartisan, employed, non-Kurdish speaking urban dweller with an average level of wealth. In the center panel the reference individual is an employed, non-Kurdish speaking urban dweller with an average level of wealth and education. In the right panel the reference individual is a nonpartisan, employed, non-Kurdish speaking individual with an average level of wealth and education. The figure is constructed using estimates from the logistic and LISTIT regressions as reported in Table 4. 